\title{
ALK Inhibitor ASP3026
}

National Cancer Institute

\section{Source}

National Cancer Institute. ALK Inhibitor ASP3026. NCI Thesaurus. Code C116727.

An orally available, small molecule inhibitor of the receptor tyrosine kinase anaplastic lymphoma kinase (ALK), with potential antineoplastic activity. Upon oral administration, ASP3026 binds to and inhibits ALK tyrosine kinase, ALK fusion proteins and ALK point mutation variants. Inhibition of ALK leads to the disruption of ALK-mediated signaling and the inhibition of cell growth in ALK-expressing tumor cells. ALK belongs to the insulin receptor superfamily and plays an important role in nervous system development. ALK is not expressed in healthy adult human tissue but ALK dysregulation and gene rearrangements are associated with a series of tumors. Additionally, ALK mutations are associated with acquired resistance to small molecule tyrosine kinase inhibitors. 